\title{
Can entrepreneurial role models alleviate the fear of entrepreneurial failure?
}

\section{Eugenia Ferreto*}

Business School,

Costa Rica Institute of Technology (ITCR),

Cartago, Costa Rica

Email: eferreto@tec.ac.cr

*Corresponding author

\section{Esteban Lafuente}

Universitat Politècnica de Catalunya (UPC Barcelona Tech),

Barcelona, Spain

Email: esteban.lafuente@upc.edu

\section{Juan Carlos Leiva}

Business School,

Costa Rica Institute of Technology (ITCR),

Cartago, Costa Rica

Email: jleiva@tec.ac.cr

\begin{abstract}
This paper analyses how entrepreneurial role models alleviate the fear of entrepreneurial failure among people who are not yet involved in entrepreneurial activities. The proposed hypothesis are tested using a logistic regression model relating the presence of entrepreneurial role models and fear of failure on a unique sample drawn from the Costa Rica Global Entrepreneurship Monitor (GEM) for the year 2014. The findings of the study reveal that the presence of entrepreneurial examples reduces the fear of failure among non-entrepreneurially active individuals. This study offers insights on how entrepreneurial examples contribute to shape relevant individual perceptions related to the fear of entrepreneurial failure, which constitutes an antecedent of entrepreneurship.
\end{abstract}

Keywords: entrepreneurship; fear of failure; role models; Costa Rica.

Reference to this paper should be made as follows: Ferreto, E., Lafuente, E. and Leiva, J.C. (xxxx) 'Can entrepreneurial role models alleviate the fear of entrepreneurial failure?’, Int. J. Business Environment, Vol. X, No. Y, pp.xxx-xxx.

Biographical notes: Eugenia Ferreto is a $\mathrm{PhD}$ candidate and Professor in the Business School at the Costa Rica Institute of Technology (ITCR). Since 2010, she is the Director of the Business Incubation Center. She is also member of the editorial review board of the Iberoamerican Journal of Accounting, Economics and Management. Her research mainly focuses on the analysis of the entrepreneurial activity, its determinants and economic impact. 
Esteban Lafuente completed his $\mathrm{PhD}$ and an Associate Professor in the Department of Management at the Universitat Politècnica de Catalunya (UPC Barcelona Tech). His research interests mostly focus on the economic analysis of organisations, with special emphasis on models of managerial economics and productivity analysis. Also, he is interested in entrepreneurial activities and business creation, and their economic benefits from a territorial perspective. His research work has been published in, among others, International Journal of Production Economics, British Journal of Management, Journal of Technology Transfer, Journal of Business Research, Regional Studies, Entrepreneurship and Regional Development, and Technovation.

Juan Carlos Leiva completed his PhD and a Professor in the Business School at the Costa Rica Institute of Technology (ITCR). He is the Editor-in-Chief of the Journal Tec. Empresarial (Costa Rica Institute of Technology, ITCR). His research primarily focuses on the analysis of entrepreneurial activities and their economic impact as well as on topics related to innovation performance and SMEs. His research has been published, among others, in ARLA, Sustainability, JEFAS and CEPAL Review.

\section{Introduction}

A great deal of empirical research shows that entrepreneurial role models are a key aspect for effective learning, thus conditioning the decision to engage in entrepreneurial activities (e.g., Bosma et al., 2012; Lafuente and Vaillant, 2013; Lafuente et al., 2007; Van Auken et al., 2006). Knowing entrepreneurs provides individuals with examples or peers that inspire them to become entrepreneurs (Gibson, 2004). By sharing their knowledge and business experience, entrepreneurial role models facilitate the discovery process of business opportunities at the early stages of the entrepreneurial process (Karimi et al., 2014; Laviolette et al., 2012; Vaillant and Lafuente, 2007).

Observation and interaction with entrepreneurial role models is conducive to a special type of learning that permits to gain insights into a variety of tasks, thus reducing information asymmetries via the generation of information that mitigates the ambiguity and uncertainty associated with entrepreneurship. According to the postulates of the social learning theory, individuals listen to other entrepreneurs (role models) because they can assist them in performing entrepreneurship-related tasks and developing entrepreneurial skills (Gibson, 2004; Minniti and Nardone, 2007). The generally positive influence of role models is not only linked to the access to increased entrepreneurial knowledge stocks, but also to the entrepreneurial learning behaviours that they promote (Rae, 2000).

Besides learning, entrepreneurial role models provide motivation and inspiration, and they constitute a credible and reliable source of information that can transmit values and attitudes. That is, role models are seen as models of reflection and action (Gibson, 2004; Laviolette et al., 2012).

By analysing the attributes, behaviours and skills necessary to achieve the desired objective, individuals perceive similarities in the entrepreneurs that they consider as valid role models, thus reducing the fear of entrepreneurial (Gibson, 2004; Wyrwich et al., 2016). Nevertheless, the positive impact of role models is not exclusive domain of entrepreneurial activities. 
Contrary to most research on entrepreneurship - i.e., primarily focused on the effect of entrepreneurial role models and fear of failure on entrepreneurial behaviour (see e.g., Bosma et al., 2012; Chlosta et al., 2012; Contín-Pilart and Larraza-Kintana, 2015; Lafuente et al., 2007) - the analysis of the relationship between role models and fear of failure is the focus of our study.

Fear of entrepreneurial failure, understood as a social trait connected to the perceived stigmatisation of business failure (Driga et al., 2009), has been identified as an impediment to entrepreneurship (Lafuente et al., 2007). The consequences of business failure - i.e., social embarrassment - may negatively influence individuals' entrepreneurial choices. In this sense, recent work suggests that role models contribute to mitigate the potentially negative effects of fear of failure (Sepúlveda and Bonilla, 2014; Wyrwich et al., 2016).

Therefore, the objective of this study is to evaluate the effect of knowing entrepreneurs on individuals' perceived fear of failure. We argue that the potentially beneficial effects of role models will translate into a lower probability of fear of entrepreneurial among non-entrepreneurially active individuals, and that this effect constitutes an antecedent of entrepreneurship.

By assessing the connection between role models and fear of failure among nonentrepreneurs, this study adopts a different approach that seeks to unveil how the recent entrepreneurs' knowledge can act as a catalyst to remove social barriers to entrepreneurship - in our case, fear of failure - and, thus, increase the desirability of the entrepreneurial career among non-entrepreneurially active individuals, that is, the entrepreneurs of the future.

The empirical application employs a unique sample of 1905 individuals drawn from the Costa Rica Global Entrepreneurship Monitor (GEM) for the year 2014. In order to control for potential biases arising from the heterogeneous levels of experience of individuals with entrepreneurial experience viz.-a-viz. non-entrepreneurs, we restrict the analysis to non-entrepreneurially active individuals whose perception of fear of failure is not conditioned by previous or actual entrepreneurial experience.

The remainder of the manuscript is organised as follows. Section 2 presents the theory that underpins this study. The data, the description of the study variables and the method are described in Section 3. Section 4 presents the empirical results. Finally, Section 5 offers the concluding remarks, implications and future research lines.

\section{Background theory and hypotheses development}

\subsection{Social traits affecting entrepreneurship}

Literature on entrepreneurship emphasises the role of different economic and non-economic incentives in shaping new business formation among individuals (e.g., González-Pernía et al., 2012; Lafuente et al., 2007; Vendrell-Herrero et al., 2014).

This study examines whether or not social-cultural traits are correlated. The tested hypothesis is based on the analysis of two influential social traits commonly identified within the entrepreneurship literature: the social fear of entrepreneurial failure and the knowledge of entrepreneurial role models.

Within the entrepreneurial frame, the social fear of entrepreneurial failure (fear of failure) is a social trait that can act as a barrier to entrepreneurship by stigmatising 
business failure (Driga et al., 2009; Simmons et al., 2014). The social consequences of business failure (e.g., social embarrassment) may create an obstacle when it comes to engage in entrepreneurship. Cacciotti et al. (2016) suggest that the fear of entrepreneurial failure has economic and psychological components. From the economic perspective, a perception related to risk-taking and uncertainty negatively influences entrepreneurship decision-making, which often leads to opt for working for someone else. On the other hand, the psychological view that highlights that the individuals' attitude towards entrepreneurial failure is conditioned by the presence of social norms mostly deemed as shameful (Simmons et al., 2014).

At the individual level, the social stigma toward entrepreneurial failure shape economic decisions and may dissuade individuals from engaging in entrepreneurial activities (Cramer et al., 2002; Marshall, 2016).

The fear of failure is not a desirable social trait because, in many cases, failure is psychologically painful and economically costly, generates a negative effect on the individual's perceived level of confidence, and undermines individuals' self-esteem and their relationships with other entrepreneurs (Cope, 2011). Within the entrepreneurship frame, the fear of failure is connected to uncertainty and to the risks borne for individuals; however, the perceived fear of failure can help individuals to better understand, prepare and learn all the aspects of their entrepreneurial intentions (Nabi and Liñán, 2013).

The experience of entrepreneurial failure is associated with attitudes of stigma, sanctions and behaviours. From a social perspective, the failure of a business can generate stigma because the activities of entrepreneurs who ignore social regulations are subject to sanctions that harm not only entrepreneurs through the loss of commercial and exchange relationships but also potential entrepreneurial leaders who feel hurt and embarrassed by social labels and negative symbols (Simmons et al., 2014).

Fear of failure is also seen as a special type of aversion to loss, where the amount of profit that the entrepreneur can earn is measured in relation to a defined level of success. At all stages of the entrepreneurial process, various elements may contribute to increase individuals' perceived far of failure, including the risks resulting from the participation in entrepreneurial activities, as we as a number of formal - i.e., legal and financial effects of bankruptcy - and informal (social) consequences of business failure. All these elements are significant obstacles to entrepreneurial activity (Morgan and Sisak, 2016; Vaillant and Lafuente, 2007).

We now turn to the second social trait analysed in this study, namely entrepreneurial role models. The theory of social learning emphasises that individuals learn by observing the actions of a role model, that is, if the role model performs well, his or her story will encourage others to perform similar actions (Bandura, 1977). Based on the people's characteristics in social roles, individuals perceive role models as similar, which stimulate the possibility of emulating their actions and making certain decisions (Autin and Croizet, 2012; Bosma et al., 2012; Contín-Pilart and Larraza-Kintana, 2015).

In the field of entrepreneurship, the personal acquaintance of an entrepreneurial role model has a potentially positive effect on individuals' entrepreneurship entry decision-making by increasing the perception that they can achieve the desired goal (Karimi et al., 2014). In addition, role models are important at the time of choosing an entrepreneurial career because they provide good examples to imitate, inspire and convey positive messages that facilitate an individual in discovering and acting on new business ideas and opportunities at the early stages of the business creation process. That is, the 
observation and interaction between the individual and his/her role model drive learning and provide opportunities to better understand tasks and skills necessary to successfully engage in entrepreneurship (Lafuente et al., 2007).

\subsection{Entrepreneurial role models as a solution to perceived fear of failure}

In this study we argue that entrepreneurial role models contribute to mitigate the perceived fear of entrepreneurial failure. Existing research has identified two ways through which role models can alleviate perceived fear of failure, namely learning and legitimacy.

Concerning the first effect (learning), entrepreneurial role models both channel positive messages about entrepreneurship and assist individuals interested in the entrepreneurial career in discovering and acting on new business ideas and opportunities (Minniti, 2005). The interaction with other entrepreneurs (role models) fosters learning and provides opportunities to better understand the tasks and skills necessary to run a new business. By channelling their experience entrepreneurial role models reduces information costs for non-entrepreneurs (e.g., formal legal procedures, access to finance, access to suppliers), contributes to minimise uncertainty about business activities (e.g., resource organisation and allocation) (Lafuente et al., 2007; Lafuente and Vaillant, 2013; Wyrwich et al., 2016).

Therefore, the learning effect of entrepreneurial role models can reduce the perceived stigma toward business failure (fear of failure) by providing individuals with relevant information that can clarify relevant aspects of the entrepreneurial process, thus minimising part of the inherent risks of entrepreneurship (Karimi et al., 2014; Marshall, 2016; McVea, 2009).

Regarding the second effect (legitimacy), it should be noted that entrepreneurship can be an attractive career choice for individuals (economically and socially) (Driga et al., 2009; Lafuente et al., 2007). Together with enhanced market mechanisms, this positive perception may explain the reported rise in the number of entrepreneurial ventures, which, in turn, increase the social acceptance of entrepreneurship (Etzioni, 1987). The relationship between increased rates of entrepreneurship and superior social legitimisation of entrepreneurship may produce a virtuous circle that may perpetuate entrepreneurial behaviour over time.

The personal knowledge of an entrepreneurial role model provides both learning and legitimacy that contribute to minimise the perceived fear of entrepreneurial failure and, consequently, encourage to turn entrepreneurial ambitions into reality. We argue that both effects help to reduce the stigma associated with the fear of failure. Knowledge transfer (learning effect) reduces the ambiguity that many times obscures the steps of the entrepreneurial process, while legitimacy increases the attractiveness of the entrepreneurial career (Bosma et al., 2012; Lafuente et al., 2007). From these theoretical arguments and evidence, we hypothesise:

H1 Among non-entrepreneurially active individuals, the personal knowledge of an entrepreneur (role model) reduces the social fear of failure. 


\section{Data, variables and method}

\subsection{Data}

This study evaluates how the knowledge of a role model influences the perceived fear of failure. The proposed hypothesis is tested using a unique primary dataset for the year 2014 drawn from the Adult Population Survey (APS) of the Costa Rican GEM.

In every participating country, the GEM survey is conducted by a professional market investigation business selected and monitored directly by the International GEM Consortium. The final dataset comprises data for a randomly selected sample of Costa Ricans aged between 18 and 65 inclusive.

At a global scale, the data produced by GEM is recognised as a robust and valid source of information to study the entrepreneurship phenomenon, which is evident in the large stock of papers that evaluate entrepreneurial behaviours using GEM data (e.g., Bosma et al., 2012; Driga et al., 2009; Lafuente et al., 2007; Vaillant and Lafuente, 2007; Wyrwich et al., 2016).

The original database contains information for 2058 Costa Rican adults. Nevertheless, an important consideration related to the sample selection is worth mentioning. Our analysis restricts to non-entrepreneurially active respondents, that is, we excluded from the sample individuals with past entrepreneurial experience, actual entrepreneurs, and individuals who are currently in the process of initiating a new business. The arguments to include in the sample non-entrepreneurially active individuals are twofold. First, we propose that role models alleviate perceived fear of entrepreneurial failure. In this case, the inclusion of past and/or actual entrepreneurially active individuals implies an 'entrepreneurial bias' as active entrepreneurship is evidence that these individuals who engage in entrepreneurship arguably have overcome their fear of failure. Second, from an empirical perspective, the exclusion of past and actual entrepreneurs permits to distinguish the true effect of entrepreneurial role models on individuals' fear of failure from the potentially puzzling effect of role models on perceived fear of failure in individuals with different levels of experience (Wyrwich et al., 2016).

As a result, data availability limits the sample to 1905 non-entrepreneurially active individual from Costa Rica.

\subsection{Variable definition}

\subsubsection{Perceived fear of failure}

The dependent variable analysed in this study is the self-reported fear of entrepreneurial failure. Within the GEM survey, this dichotomous variable emerges from the question of whether the social fear of failure would prevent the individual from initiating a new business $(1=$ yes, $0=$ no). The descriptive statistics presented in Table 1 show that $40.39 \%$ of respondents state that fear of failure is an obstacle to entrepreneurial activities.

\subsubsection{Entrepreneurial role model}

In this study, the key independent variable is related to the role model effect. This factor is measured via a dichotomous variable taking the value of one if the individual personally knows at least one entrepreneur who started his/her business in the last two years. In line with our theory, the effect of the personal knowledge of a recent 
entrepreneur should act as stimuli that contribute to reduce the fear of failure among individuals. In our sample, the proportion of individuals who personally know an entrepreneurial role model is 39.69\%. Additionally, the proportion of individuals with an entrepreneurial role model is significantly higher $(41.90 \%)$ among those who do not manifest a social fear of failure, compared to that of individuals who state that fear of failure is an impediment to entrepreneurship (36.41\%).

Table 1 Descriptive statistics for the selected variables

\begin{tabular}{lccc}
\hline & Full sample & No fear of failure & Fear of failure \\
\hline Fear of failure & $0.4039(0.4908)$ & 0 & 1 \\
Role model & $0.3969(0.4894)$ & $0.4190(0.4937)^{* *}$ & $0.3641(0.4813)$ \\
Gender (male) & $0.4790(0.4997)$ & $0.5132(0.5001)^{* * *}$ & $0.4286(0.4952)$ \\
Age (years) & $36.98(13.40)$ & $36.59(13.37)$ & $37.55(13.45)$ \\
Worker (dummy) & $0.2943(0.4559)$ & $0.3019(0.4593)$ & $0.2831(0.4508)$ \\
Primary studies & $0.2539(0.4354)$ & $0.2368(0.4253)^{* *}$ & $0.2792(0.4489)$ \\
Secondary studies & $0.3494(0.4769)$ & $0.3468(0.4762)$ & $0.3532(0.4783)$ \\
Post secondary education & $0.2981(0.4624)$ & $0.3080(0.3101)$ & $0.2829(0.2787)$ \\
University studies & $0.0986(0.2983)$ & $0.1074(0.3098)^{*}$ & $0.0857(0.2801)$ \\
San José & $0.3253(0.4686)$ & $0.3407(0.4741)^{*}$ & $0.3026(0.4597)$ \\
Alajuela & $0.1857(0.3890)$ & $0.1761(0.3810)$ & $0.2000(0.4003)$ \\
Cartago & $0.1222(0.3277)$ & $0.0995(0.2994)^{* * *}$ & $0.1558(0.3629)$ \\
Heredia & $0.1149(0.3190)$ & $0.1426(0.3498)^{* * *}$ & $0.0740(0.2620)$ \\
Guanacaste & $0.0740(0.2618)$ & $0.0546(0.2273)^{* * *}$ & $0.1026(0.3036)$ \\
Puntarenas & $0.0902(0.2866)$ & $0.1065(0.3086)^{* * *}$ & $0.0662(0.2489)$ \\
Limón & $0.0876(0.2828)$ & $0.0801(0.2716)$ & $0.0987(0.2985)$ \\
Number of observations & 1,905 & 1,136 & 769 \\
\hline
\end{tabular}

Notes: $*$, **, *** indicate significance at the $10 \%, 5 \%$ and $1 \%$, respectively (Kruskall Wallis test).

\subsubsection{Control variables}

In the proposed model specification, we control for gender, age, educational attainment, labour status, and location. Gender is measured via a dummy ( $1=$ men, $0=$ women), while age is measured in terms of years. The individual's educational attainment is considered using a set of dummy variables distinguishing people who finished primary school $(1=$ yes, $0=$ no), secondary studies $(1=$ yes, $0=$ no), post-secondary studies ( 1 = yes, $0=$ no), and university studies $(1=$ yes, $0=$ no). A dummy variable is used to measure the respondent's labour status $(1=$ worker, $0=$ unemployed $)$. Finally, a set of dummy variables that identify the respondents' location were introduced. These variables have been used in prior work dealing with entrepreneurial activities (e.g., Driga et al., 2009; Lafuente and Vaillant, 2013, Lafuente et al., 2007; Langowitz and Minniti, 2007).

In the final sample of Costa Rican respondents, note that $47.90 \%$ are men, being the proportion of men with fear of failure (51.32\%) significantly higher than that of reported for the group of people who do not perceive fear of failure (42.86\%). In line with previous work on entrepreneurship (Caliendo and Kritikos, 2010; Lafuente et al., 2007; 
Pfeiffer and Reize, 2000), the average age is 37 years old. For the education variables, it is observed that $34.94 \%$ of individuals have attained secondary education, while the proportion of individuals with post-secondary studies and university studies is $29.81 \%$ and 9.86\%, respectively. In this case, the only significant differences between individuals with and without fear of failure were found for the primary studies dummy and the university studies variable. These results are slightly lower than those reported in prior work focused on the profile of Costa Rican entrepreneurs (Leiva, 2013; Messina and Hochsztain, 2015).

Finally, $29.43 \%$ of the sampled individuals are employed; and 32.53\% reside in the capital city (San Jose).

\subsection{Method}

To verify whether the presence of an entrepreneurial role model reduces the social fear of failure, we have chosen a binary choice model as a methodological tool. Therefore, the proposed logit model estimated by maximum likelihood has the following form (Greene, 2003):

$$
\text { Fear of failure }{ }_{i}=\beta_{0}+\beta_{1} \text { Role }_{\text {model }}+\beta_{2} \text { Control variables }_{i}+\varepsilon_{i}
$$

In equation (1), $\beta_{0}$ is the intercept of the model, $\beta_{j}$ is the vector of coefficients estimated for each independent variable $(j)$, and $\varepsilon_{i}$ is the logistically distributed disturbance estimated for each individual $(i)$.

Note that parameters estimated by discrete choice models only show the direction of the relationship between a focal independent variable and the dependent variable. For interpretation purposes, the average marginal effect (AME) provides an estimation of the magnitude of the analysed independent variables. The AME is the average change in the probability of the response variable as a result of a variation in an independent factor across the sampled observations. Through this approach we can estimate marginal effects for each observation, thus the resulting AME not only captures individual-specific characteristics, but also gives more realistic estimation results (Greene, 2005). For each independent variable $(X)$ the AME is estimated as

$$
A M E_{X}=\frac{1}{N} \sum_{i=1}^{N}\left\{F\left(\beta X \mid X_{i}=1\right)-F\left(\beta X \mid X_{i}=0\right)\right\} .
$$

\section{Results}

The results of the logistic regression model that relates fear of failure with the role model variable are presented in Table 2. Also note that we computed the variance inflation factor (VIF) to test if coefficients are amplified due to collinearity problems. Table 2 reports the average VIF value for the regression model. The results show that for all the independent variables the VIF value is below ten - a common cut-off threshold used to evaluate collinearity - which confirms that our model does not suffer from collinearity problems (Greene, 2003). Additionally, the results of goodness of fit measures - i.e., Pseudo R2 and the proportion of correctly classified observations - further validate the robustness of the proposed model. 
Concerning the control variables, the findings in Table 2 indicate that the probability of perceiving fear of entrepreneurial failure as an obstacle to entrepreneurship is lower among men. More concretely, the result of the average marginal effect shows that, in our sample, the probability of having fear of entrepreneurial failure is 8.06 percentage points lower among men, relative to the probability of women. This result highlighting that, in our sample, women are more likely to perceive fear of failure is similar to the findings reported by Sepúlveda and Bonilla (2014) and Wyrwich et al. (2016).

The coefficients for the variables age and labour status are not statistically significant. On contrary, the findings for the education dummies reveal that, compared to the probability of people with primary education, the probability of having fear of failure is 5.45 percentage points higher among people with post secondary education, while the probability of fear of failure falls 7.32 percentage points among individuals with university studies. Similar to Vaillant and Lafuente (2007), this result suggests that the cumulative level of education tends to decrease the fear of entrepreneurial failure.

Table 2 Logit regression: empirical results

\begin{tabular}{lcc}
\hline & \multicolumn{2}{c}{$\begin{array}{c}\text { Dependent variable: fear of failure among } \\
\text { non-entrepreneurs }\end{array}$} \\
\cline { 2 - 3 } & $\begin{array}{c}\text { Coefficient } \\
\text { (std. error) }\end{array}$ & $\begin{array}{c}\text { Average marginal effect } \\
\text { (std. error) }\end{array}$ \\
\hline Role model & $-0.1975(0.0998)^{* *}$ & $-0.0454(0.0229)^{* *}$ \\
Gender (1 = male) & $-0.3502(0.0999)^{* * *}$ & $-0.0806(0.0227)^{* * *}$ \\
Age (ln years) & $0.2165(0.1356)$ & $0.0498(0.0311)$ \\
Worker (dummy) & $-0.0046(0.1082)$ & $-0.0011(0.0249)$ \\
Secondary education & $0.1251(0.1206)$ & $0.0288(0.0277)$ \\
Post-secondary education & $0.2370(0.1355)^{*}$ & $0.0545(0.0311)^{*}$ \\
University studies & $-0.3180(0.1883)^{*}$ & $-0.0732(0.0432)^{*}$ \\
Territorial (province) dummies & Yes & \\
Constant & $-1.1373(0.5235)^{* *}$ & \\
Wald test (chi2) & $80.31^{* * *}$ & \\
Log likelihood & -1241.98 & \\
Pseudo R2 (McFadden) & 0.0334 & \\
Average VIF (min-max) & $1.24(1.03-1.75)$ & \\
Correctly predicted (fear of failure) & 0.6229 & \\
Correctly predicted (no fear of failure) & 0.6092 & \\
Correctly predicted (full sample) & 0.6147 & \\
Number of observations & 1,905 & \\
\hline
\end{tabular}

Notes: Robust standard errors are presented in brackets. San Jose (capital province) is the omitted regional dummy variable. $*, * *, * * *$ indicate significance at the $10 \%, 5 \%$ and $1 \%$ level, respectively.

The findings for the key independent variable of the study reveal that, among the group of non-entrepreneurs, the personal knowledge of a role model (recent entrepreneur) has a significantly negative effect on the probability of reporting fear of failure. 
More concretely, the result of the average marginal effect shows that, on average, the probability of reporting a fear of entrepreneurial failure significantly falls 4.54 percentage points among non-entrepreneurs who know a recent entrepreneur (role model), relative to the probability of non-entrepreneurs who do not know an entrepreneurial role model. This result is in line with the findings by Sepúlveda and Bonilla (2014) for four Latin American countries (Argentina, Brazil, Chile, and Mexico) and Wyrwich et al. (2016) for Germany.

The negative relationship between role models and perceived fear of failure corroborates our theoretical argument that knowing an entrepreneurial role model contributes to reduce the social stigma linked to entrepreneurial failure among non-entrepreneurs by transmitting the necessary knowledge (learning effect) and increasing the attractiveness of the entrepreneurial career (legitimacy effect) (Gibson, 2004; Lafuente and Vaillant, 2013; Lafuente et al., 2007; Politis and Gabrielsson, 2009).

Therefore, we confirm the study hypothesis (H1) that proposes that, among individuals not involved in entrepreneurial activities, the personal knowledge of a role model reduces the perceived fear of failure.

\section{Conclusions, implications and lines of future research}

\subsection{Theoretical contribution}

The study presented in this paper has produced novel empirical evidence on the connection between the knowledge of entrepreneurial role models and the social fear of entrepreneurial failure in a developing economy.

In the proposed model, we hypothesised that knowing a recent entrepreneur (role model) will significantly reduce the perceived fear of failure. Fear of business failure is a widely recognised impediment to entrepreneurial activities, and our study provides a compelling vision of how non-entrepreneurs can capitalise on the knowledge and legitimacy generated by the contact with recent entrepreneurs to reduce their perceived fear of entrepreneurial failure, which constitutes a relevant antecedent of individual actions oriented to the creation of new ventures.

By focusing on the group of non-entrepreneurially active individuals, the results of our empirical analysis highlight that the level of fear of business failure in a focal society can be reduced by promoting actions - i.e., interaction with entrepreneurs - that enhance learning and social legitimacy.

Therefore, this study contributes to fuel the academic debate on whether increased contact with entrepreneurs is a valid mechanism to enhance the entrepreneurial ecosystem of territories by encouraging the entrepreneurial intention of individuals without entrepreneurial experience in the short- and long-run. Additionally, our study extends the emerging literature on the relationship between the knowledge of entrepreneurial role models and fear of business failure (Sepúlveda and Bonilla, 2014; Wyrwich et al., 2016).

\subsection{Policy implications}

A number of relevant policy implications can be drawn from the results of this paper. A high rate of fear of failure within any focal society is evidence of, among other things, a 
low valuation of the entrepreneurial career which constitutes an antecedent of potentially low rates of entrepreneurship in the future. Therefore, policy interventions aimed at fostering entrepreneurship should not exclusively focus on entrepreneurially active. Rather, entrepreneurship support policies should also target non-entrepreneurially active individuals and people without entrepreneurial experience. But, the inputs generated by our results suggest that the orientation of support policies based on the promotion of contact with entrepreneurs is conditional on the targeted group of beneficiaries.

On the one hand, by promoting the contact with recent entrepreneurs, individuals engaged in the entrepreneurial process may obtain relevant information that contributes to reduce the uncertainty often linked to the entrepreneurship career. In this case, a policy focused on the promotion of networking with existing entrepreneurs should emphasise the learning effects of such entrepreneurial role models.

On the other hand, policies seeking to develop a network connecting entrepreneurs and individuals without entrepreneurial experience may prove themselves effective if they first focus on enhancing the social legitimacy of the entrepreneurial career. The social valuation of entrepreneurship helps to shape the quality of territories' entrepreneurial ecosystem (Lafuente et al., 2016). Entrepreneurship support policies will turn sterile if the territory does not enjoy an entrepreneurship culture that promotes the nurturing of potential entrepreneurs to the market. Therefore, the development of an entrepreneurial culture within the territory should precede decision-making related to the allocation of resources to promote entrepreneurial ventures. This way, the objective of networks between entrepreneurial role models and individuals without entrepreneurial experience should be to reduce the stigma of business failure in the society (fear of failure) by informing people about the benefits (and costs) of the entrepreneurial career as well as to increase the social legitimacy of entrepreneurship (Kollmann et al., 2017). This type of role model network - i.e., focused on enhanced legitimisation of entrepreneurship - will arguably materialise in higher rates of individuals willing to engage in entrepreneurship and, subsequently, higher rates of entrepreneurship (Lafuente and Vaillant, 2013; Van Gelderen et al., 2015).

Finally, the results of this study pointing to a positive effect of both the exposure to entrepreneurial role models and higher education levels for reducing the perceived fear to business failure among non-entrepreneurs suggest that policy actions should also target the education system. By promoting the contact with entrepreneurs or enterprise learners, specifically designed education strategies can contribute both to channel the accumulated knowledge of role models to students and to increase the legitimacy of business ownership among students who are the entrepreneurs of the future. Similar policies have been implemented in the UK with important results (Tarling et al., 2016).

\subsection{Limitations and suggestions for further research}

To conclude, it must be mentioned a series of limitations to the present research that, in turn, represent opportunities for future research. First, and similar to most studies based on GEM data (e.g., Driga et al., 2009; Sepúlveda and Bonilla, 2014; Wyrwich et al., 2016), our study does not permit to scrutinise the influence of different types of role models on the individuals' perceived fear of failure. We present various interpretations of how role models contribute to reduce fear of failure; however, we do not evaluate how this relationship is affected by the contact with successful and unsuccessful entrepreneurs 
(Chen et al., 2016), nor do we evaluate how the specific legitimacy of the known entrepreneur influences the relationship between role models and fear of failure. Specifically designed future research on this issue would be valuable. In a closely related manner, a second future area of research should focus on the analysis of the potentially differentiating impact on fear of failure of role models in different settings (rural and urban).

Finally, and with the objective to further validate and generalise the findings presented in this study, future research should replicate our analysis in other geographic contexts.

\section{References}

Autin, F. and Croizet, J. (2012) 'Improving working memory efficiency by reframing metacognitive interpretation of task difficulty', Journal of Experimental Psychology: General, DOI: $10.1037 / \mathrm{a} 0027478$.

Bandura, A. (1977) 'Self-efficacy: toward a unifying theory of behavioral change', Psychology Review, Vol. 84, No. 2, pp.191-215.

Bosma, N., Hessels, J., Schutjens, V., Van Praag, M. and Verheul, I. (2012) 'Entrepreneurship and role models', Journal of Economic Psychology, Vol. 33, No. 2, pp.410-424 [online] http://doi.org/10.1016/j.joep.2011.03.004.

Cacciotti, G., Hayton, J.C., Mitchell, J.R. and Giazitzoglu, A. (2016) 'A reconceptualization of fear of failure in entrepreneurship’, Journal of Business Venturing, Vol. 31, No. 3, pp.302-325 [online] http://doi.org/10.1016/j.jbusvent.2016.02.002.

Caliendo, M. and Kritikos, A. (2010) 'Start-ups by the unemployed: characteristics, survival and direct employment effects’, Small Business Economics, Vol. 35, No. 1, pp.71-92 [online] http://doi.org/ 10.1007/s11187-009-9208-4.

Chen, N., Ding, G. and Li, W. (2016) 'Do negative role models increase entrepreneurial intentions? The moderating role of self-esteem’, Basic and Applied Social Psychology, pp.4-14 [online] http://doi.org/10.1080/01973533.2016.1217223.

Chlosta, S., Patzelt, H., Klein, S.B. and Dormann, C. (2012) 'Parental role models and the decision to become self-employed: the moderating effect of personality', Small Business Economics, Vol. 38, No. 1, pp.121-138 [online] http://doi.org/10.1007/s11187-010-9270-y.

Contín-Pilart, I. and Larraza-Kintana, M. (2015) 'Do entrepreneurial role models influence the nascent entrepreneurial activity of immigrants?', Journal of Small Business Management, Vol. 53, No. 4, pp.1146-1163 [online] http://doi.org/10.1111/jsbm.12153.

Cope, J. (2011) 'Entrepreneurial learning from failure: an interpretative phenomenological analysis', Journal of Business Venturing, Vol. 26, No. 6, pp.604-623 [online] http://doi.org/ 10.1016/j.jbusvent.2010.06.002.

Cramer, J.S., Hartog, J., Jonker, N. and Van Praag, C.M. (2002) 'Low risk aversion encourages the choice for entrepreneurship: an empirical test of a truism', Journal of Economic Behavior and Organization, Vol. 48, No. 1, pp.29-36 [online] http://doi.org/10.1016/S0167-2681(01)002220.

Driga, O., Lafuente, E. and Vaillant, Y. (2009) 'Reasons behind the relatively lower entrepreneurial activity levels of rural women: looking into rural Spain', Sociologia Ruralis, Vol. 49, No. 1, pp.70-96 [online] http://doi.org/10.1111/j.1467-9523.2008.00475.x.

Etzioni, A. (1987) 'Entrepreneurship, adaptation and legitimation: a macro-behavioral perspective', Journal of Economic Behavior \& Organization, Vol. 8, No. 2, pp.175-189 [online] http://doi.org/10.1016/0167-2681(87)90002-3.

Gibson, D.E. (2004) 'Role models in career development: new directions for theory and research', Journal of Vocational Behavior, Vol. 65, No. 1, pp.134-156 [online] http://doi.org/10.1016/ S0001-8791(03)00051-4. 
González-Pernía, J.L., Peña-Legazkue, I. and Vendrell-Herrero, F. (2012) 'Innovation, entrepreneurial activity and competitiveness at a sub-national level', Small Business Economics, Vol. 39, No. 3, pp.561-574.

Greene, W. (2003) Econometric Analysis, 5th ed., Prentice Hall, Upper Saddler River, NJ.

Greene, W. (2005) 'Reconsidering heterogeneity in panel data estimators of the stochastic frontier model', Journal of Econometrics, Vol. 126, No. 2, pp.269-303 [online] http://doi.org/10.1016/ j.jeconom.2004.05.003.

Karimi, S., Biemans, H.J., Lans, T., Chizari, M. and Mulder, M. (2014) 'Effects of role models and gender on students' entrepreneurial intentions', European Journal of Training and Development, Vol. 38, No. 8, pp.694-727 [online] http://doi.org/10.1108/EJTD-03-20130036.

Kollmann, T., Stöckmann, C. and Kensbock, J.M. (2017) 'Fear of failure as a mediator of the relationship between obstacles and nascent entrepreneurial activity - an experimental approach', Journal of Business Venturing, Vol. 32, No. 3, pp.280-301 [online] http://doi.org/ 10.1016/j.jbusvent.2017.02.002.

Lafuente, E. and Vaillant, Y. (2013) 'Age driven influence of role-models on entrepreneurship in a transition economy', Journal of Small Business and Enterprise Development, Vol. 20, No. 1, pp.181-203 [online] http://doi.org/10.1108/14626001311298475.

Lafuente, E., Szerb, L. and Acs, Z.J. (2016) 'Country level efficiency and national systems of entrepreneurship: a data envelopment analysis approach', Journal of Technology Transfer, Vol. 41, No. 6, pp.1260-1283 [online] http://doi.org/10.1007/s10961-015-9440-9.

Lafuente, E., Vaillant, Y. and Rialp, J. (2007) 'Regional differences in the influence of role-models: comparing the entrepreneurial process of Rural Catalonia', Regional Studies, Vol. 41, No. 6, pp.779-796 [online] http://doi.org/10.1080/00343400601120247.

Landier, A. (2005) ‘Entrepreneurship and the stigma of failure’, SSRN Electronic Journal, pp.1-39 [online] http://doi.org/10.2139/ssrn.850446.

Langowitz, N. and Minniti, M. (2007) 'The entrepreneurial propensity of women', Entrepreneurship: Theory and Practice, Vol. 31, No. 3, pp.341-364 [online] http://doi.org/ 10.1111/j.1540-6520.2007.00177.x.

Laviolette, E., Lefebvre, M. and Brunel, O. (2012) 'The impact of story bound entrepreneurial role models on self-efficacy and entrepreneurial intention', International Journal of Entrepreneurial Behavior \& Research, Vol. 8, No. 6, pp.720-742 [online] http://doi.org/ 10.1108/13552551211268148.

Leiva, J.C. (2013) ‘¿Quién crea MiPymes en Costa Rica?’, Tec. Empresarial, Vol. 7, No. 2, pp.9-17 [online] http://dx.doi.org/10.18845/te.v7i2.1509.

Marshall, D.R. (2016) 'From employment to entrepreneurship and back: a legitimate boundaryless view or a bias-embedded mindset?', International Small Business Journal, Vol. 34, No. 5, pp.683-700 [online] http://doi.org/10.1177/0266242615581853.

McVea, J.F. (2009) 'A field study of entrepreneurial decision-making and moral imagination', Journal of Business Venturing, Vol. 24, No. 5, pp.491-504 [online] http://doi.org/10.1016/ j.jbusvent.2008.07.003.

Messina, M. and Hochsztain, E. (2015) 'Factores de éxito de un emprendimiento: Un estudio exploratorio con base en técnicas de data mining (Entrepreneurial success factors: an exploratory study based on data mining techniques)', Tec. Empresarial, Vol. 9, No. 1, pp.30-40 [online] http://dx.doi.org/10.18845/te.v9i1.2206.

Minniti, M. (2005) 'Entrepreneurship and network externalities', Journal of Economic Behavior \& Organization, Vol. 57, No. 1, pp.1-27 [online] http://doi.org/10.1016/j.jebo.2004.10.002.

Minniti, M. and Nardone, C. (2007) 'Being in someone else's shoes: the role of gender in nascent entrepreneurship', Small Business Economics, Vol. 28, Nos. 2-3, pp.223-238 [online] http://doi.org/10.1007/s11187-006-9017-y. 
Morgan, J. and Sisak, D. (2016) 'Aspiring to succeed: a model of entrepreneurship and fear of failure', Journal of Business Venturing, Vol. 31, No. 1, pp.1-21 [online] http://doi.org/ 10.1016/j.jbusvent.2015.09.002.

Nabi, G. and Liñán, F. (2013) 'Considering business start-up in recession time: the role of risk perception and economic context in shaping the entrepreneurial intent', International Journal of Entrepreneurial Behaviour \& Research, October, Vol. 19, pp.633-655 [online] http://doi.org/10.1108/IJEBR-10-2012-0107.

Pfeiffer, F. and Reize, F. (2000) 'Business start-ups by the unemployed: an econometric analysis based on firm data', Labour Economics, Vol. 7, No. 5, pp.629-663 [online] http://doi.org/ 10.1016/S0927-5371 (00)00016-6.

Politis, D. and Gabrielsson, J. (2009) 'Entrepreneurs' attitudes towards failure: an experiential learning approach', International Journal of Entrepreneurial Behaviour \& Research, Vol. 15, pp.364-383 [online] http://doi.org/10.1108/13552550910967921.

Rae, D. (2000) 'Understanding entrepreneurial learning: a question of how?', International Journal of Entrepreneurial Behavior \& Research, Vol. 6, No. 3, pp.145-159 [online] http://doi.org/ 10.1108/13552550010346497.

Sepúlveda, J.P. and Bonilla, C.A. (2014) 'The factors affecting the risk attitude in entrepreneurship: evidence from Latin America’, Applied Economics Letters, Vol. 21, No. 8, pp.573-581 [online] http://doi.org/10.1080/13504851.2013.875104.

Simmons, S.A., Wiklund, J. and Levie, J. (2014) 'Stigma and business failure: implications for entrepreneurs' career choices', Small Business Economics, Vol. 42, No. 3, pp.485-505 [online] http://doi.org/10.1007/s11187-013-9519-3.

Tarling, C., Jones, P. and Murphy, L. (2016) 'Influence of early exposure to family business experience on developing entrepreneurs', Education+ Training, Vol. 58, Nos. 7/8, pp.733-750.

Vaillant, Y. and Lafuente, E. (2007) 'Do different institutional frameworks condition the influence of local fear of failure and entrepreneurial examples over entrepreneurial activity?', Entrepreneurship and Regional Development, Vol. 19, No. 4, pp.313-337 [online] http://doi.org/10.1080/08985620701440007.

Van Auken, H., Fry, F. and Stephens, P. (2006) 'The influence of role models on entrepreneurial intentions', Journal of Developmental Entrepreneurship, Vol. 11, No. 2, pp.1-10 [online] http://doi.org/10.1016/j.jbusvent.2010.01.001.

Van Gelderen, M., Kautonen, T. and Fink, M. (2015) 'From entrepreneurial intentions to actions: self-control and action-related doubt, fear, and aversion', Journal of Business Venturing, Vol. 30, No. 5, pp.655-673 [online] http://doi.org/10.1016/j.jbusvent.2015.01.003.

Vendrell-Herrero, F., González-Pernía, J.L. and Peña-Legazkue, I. (2014) 'Do incentives matter to promote high technology-driven entrepreneurial activity?', International Entrepreneurship and Management Journal, Vol. 10, No. 1, pp.43-66.

Wyrwich, M., Stuetzer, M. and Sternberg, R. (2016) 'Entrepreneurial role models, fear of failure, and institutional approval of entrepreneurship: a tale of two regions', Small Business Economics, Vol. 46, No. 3, pp.467-492 [online] http://doi.org/10.1007/s11187-015-9695-4. 